\title{
ANALYSIS OF THE CORRELATION BETWEEN THE STATIC AND FATIGUE TEST RESULTS OF THE INTERLAYER BONDINGS OF ASPHALT LAYERS
}

\begin{abstract}
A. SZYDLO ${ }^{1}$, K. MALICKI ${ }^{2}$
The bonding state of the asphalt layers in a road pavement structure significantly affects its fatigue life. These bondings, therefore, require detailed tests and optimization. In this paper, the analyses of the correlation between the results of laboratory static tests and the results of fatigue tests of asphalt mixture interlayer bondings were performed. The existence of the relationships between selected parameters was confirmed. In the future, the results of these analyses may allow for assessment of interlayer bondings' fatigue life based on the results of quick and relatively easy static tests.
\end{abstract}

Keywords: Asphalt mixture interlayer bondings, fatigue life.

\section{INTRODUCTION}

The structure of flexible road pavement consists of interconnected layers of asphalt mixtures in the upper section. The state of bonding between the layers plays an important role in the durability of the whole structure. In the absence of an adequate bond, interlayer bond weakening and acceleration of road pavement degradation occur $[1,2,3,4,5]$. Typically, relatively easy and quick static methods are used for laboratory evaluation of interlayer bonding strength. However, interlayer bondings are subject to dynamic load coming from car wheels. Thus, their degradation over time should rather be seen as a fatigue process.

Static and fatigue tests of interlayer bondings were conducted by Diakhaté et al. [6]. A comparison of the test results was performed and a formula was proposed to determine the fatigue life of the

\footnotetext{
${ }^{1}$ Prof., DSc., PhD., Eng., Wroclaw University of Technology, Faculty of Civil Engineering, Ul. Wybrzeże Stanisława Wyspiańskiego 41,50-370 Wroclaw, Poland, e-mail: antoni.szydlo@pwr.wroc.pl

${ }^{2}$ PhD., Eng., Cracow University of Technology, Faculty of Civil Engineering, Ul. Warszawska 24,

31-155 Krakow, Poland, e-mail: kmalicki@pk.edu.pl
} 
bonding. Fatigue tests were also carried out by Jaskuła [7]. It was observed that, at high shear stress, the factor determining the durability of the bonding is the occurrence of the interlayer tack coat. In this paper, an attempt was made to analyze the correlation between the results of static tests and fatigue tests of interlayer bondings carried out under shear mode. By comparing the results, the occurrence of significant trends and relationships were sought. Fatigue analysis is based on the results obtained by an individual laboratory research method [8]. Similar analyses, in the future, may allow for assessment of fatigue life of asphalt mixture interlayer bondings based on the results of quick and relatively easy static tests. Thus, it is a key issue both from the scientific and technical point of view as well as the economic one.

\section{RESEARCH METHODS AND THE EVALUATION PARAMETERS OF INTERLAYER BONDING PERFORMANCE}

The tests on interlayer bondings were conducted in shear mode in the Leutner apparatus using static load and cyclic load causing the fatigue process. The tests were carried out at a temperature of $+20^{\circ}$ C. This paper presents only selected parameters and the most important elements of the research methods used; their wider description can be found in the literature $[8,9,10]$.

\subsection{STATIC TESTS}

The static tests were based on the German manual [11] and its Polish counterpart [12]. The Leutner apparatus used in the shear tests is shown in Figure 1.

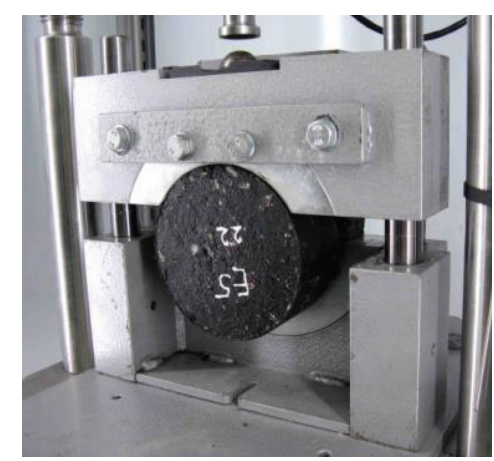

Fig. 1. The Leutner apparatus for testing asphalt mixture interlayer bondings under shear load together with the sample prepared for testing 
During the test, the equilibrium path of the interlayer bonding performance between an applied shear stress $t$ and occurring vertical displacement $\mathrm{p}$ is achieved. The shear stress was determined as the ratio of shear force to the sheared surface area of the specimen. A sample graph for the G1 sample is shown in Figure 2.

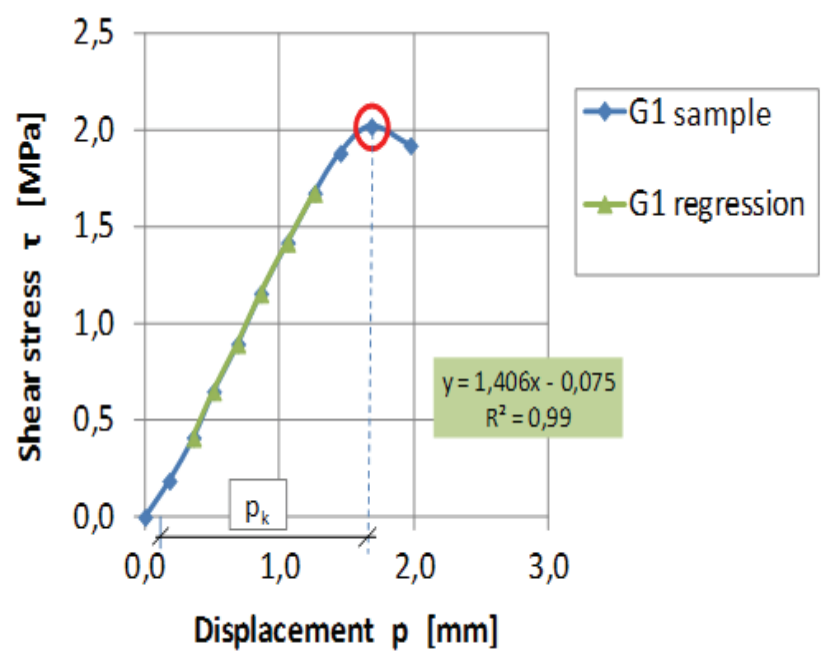

Fig. 2. Equilibrium path of the interlayer bonding performance for the G1 sample with a diameter of $100 \mathrm{~mm}$

The analysis of the resulting equilibrium path can be differentiated into four typical work stages of bonding that can be described using the selected parameters.

A zero stage of a variable length occurs at the beginning of the test and is associated with an adjustment of the sample to the testing apparatus. It is not included in the basic description of the material performance.

In the next, or first work stage, the period of stable response of the tested bonding is visible. Through the regression method, a line tangent to the graph $t-p$ is determined, which is denoted by the green line in Figure 2. The extension of the regression line to the abscissa allows for introducing a parameter of the adjusted displacement $p_{k}$ and allows elimination of the influence of the zero stage on further descriptions of the bonding performance. $p_{k}$ parameter is defined as a displacement between the point of intersection of the tangent to the function with the abscissa and the displacement corresponding to the maximum tangential stress. 
The resulting linear relationship describes solid rigidity of the bonding at this stage of its operation. This rigidity can be expressed by the Goodman model and written as an interlayer reaction tangential modulus $K[\mathrm{MPa} / \mathrm{mm}]$ according to the following formula [1]:

$$
K=\frac{d \tau}{d p_{k}}
$$

where:

$d \tau$ - increase of interlayer shear stress at the stage of solid rigidity of the bonding [MPa], $d p_{k}-$ increment of adjusted interlayer displacement corresponding to the growth of shear stress $d \tau[\mathrm{mm}]$.

The second instantaneous stage concerns the moment of maximum shear stress, marked in Figure 2 with a red circle. The evaluation parameter of this stage is the shear strength of the bonding $\tau_{c}$ $[\mathrm{MPa}]$, defined as the ratio of the maximum shear force set to the surface area of the sample subjected to shear [12].

After obtaining the maximum value of shear stress, a third agreed stage of the work occurs in which it is assumed that the bonding is damaged and no longer carries the load.

Thus, whereas four stages of bonding operation (including the zero stage) were distinguished, only the first and second stages were picked for further analysis. The parameters adopted for the operation description for those stages are summarized in Table 1.

Table 1. Parameters of bonding operation description for the selected stages

\begin{tabular}{|c|c|c|c|}
\hline Stage number & Stage name & Evaluation parameters & $\begin{array}{c}\text { Parameter } \\
\text { designation }\end{array}$ \\
\hline I & Solid rigidity stage & Interlayer reaction tangential modulus & $K$ \\
II $^{*}$ & Strength stage & Adjusted displacement & $p_{k}$ \\
\hline
\end{tabular}

\subsection{FATIGUE TESTS}

In the development of interlayer bonding strength test methods, a method of direct shear under cyclic load was developed. The test was carried out in a controlled stress mode with a coefficient of cycle asymmetry $R=0$. The load at a frequency of $0.833 \mathrm{~Hz}$ with a duration of $240 \mathrm{~ms}$ was applied. The stand for the fatigue test of interlayer bondings is shown in Figure 3. 


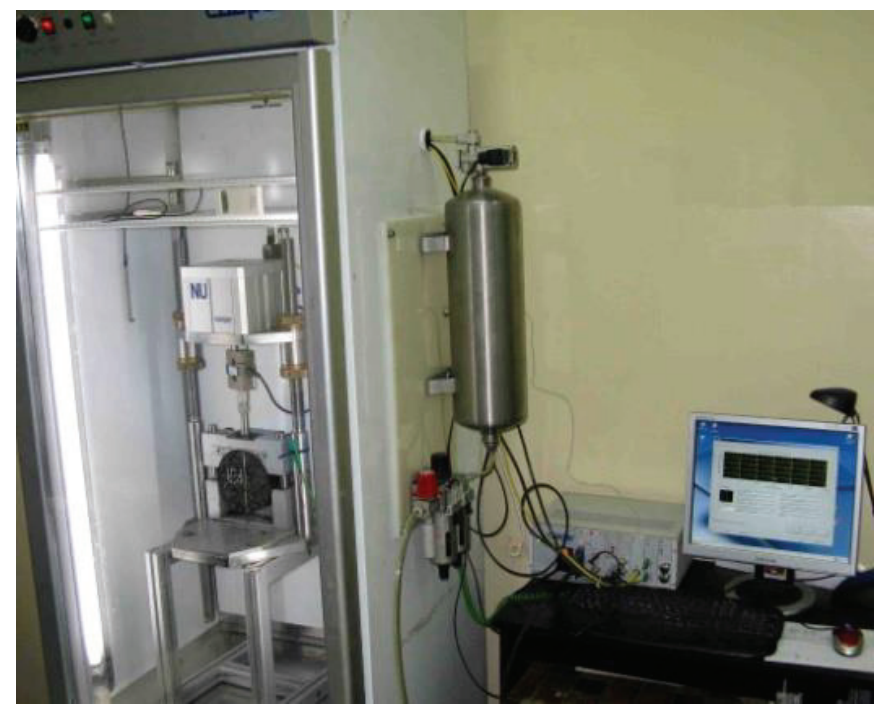

Fig. 3. Stand for fatigue tests using shearing

The developed fatigue testing method was based on the concept of dissipated energy by Van Dijk [13], which found a widespread use in the research of the asphalt mixture fatigue process [14, 15, $16,17]$. At sinusoidal loading the dissipated energy in a cycle in testing material can be represented by the following formula:

$$
W=\pi \cdot \sigma \cdot \varepsilon \cdot \sin \varphi
$$

where:

$W$ - dissipated energy per cycle, per unit volume $\left[\mathrm{J} / \mathrm{m}^{3}\right], \sigma, \varepsilon$ - stress and strain amplitude [MPa], [-], $\varphi-$ phase angle [rad].

The method assumes that there are three phases of material degradation: the initial stabilization phase, the phase of micro-crack initiation and propagation and the phase of macro-crack formation and propagation leading to the destruction of the material. An example of interlayer bonding degradation in the form of changes in displacement $u$ during the fatigue test is shown in Figure 4. 


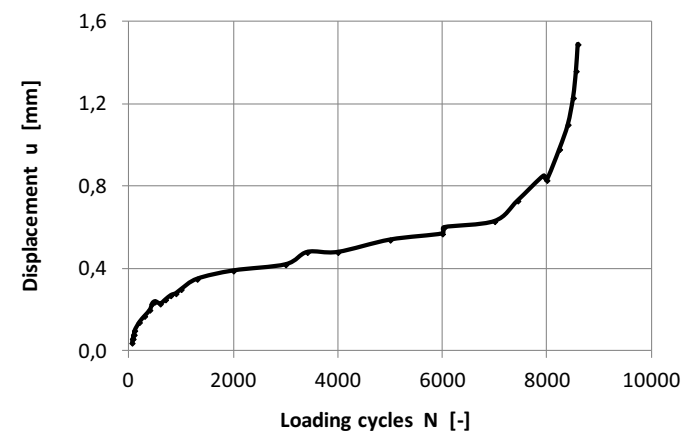

Fig. 4. Displacement in interlayer bonding of G5 sample during the fatigue test

Using a dissipated energy parameter at the beginning of the test and the dissipated energy in the given load cycle, their ratio is determined, written as a symbol of the ER (Energy Ratio). It may be represented by the product of the asphalt mixture stiffness modulus in the given load cycle and the number of load cycles $N$. The shear stiffness modulus for the interlayer bonding $\Delta K[\mathrm{MPa} / \mathrm{mm}]$ was defined by following formula [6]:

$$
\Delta K(N)=\frac{\Delta f}{A \cdot u(N)}
$$

where:

$\Delta f$ - range of the shear force $[\mathrm{kN}], u$ - displacement in the given load cycle [mm], $A$ - initial cross-sectional area of the sheared sample $\left[\mathrm{mm}^{2}\right]$.

For such defined parameters, it is possible to determine maximal coefficient $E R(N)$. It was identified with the occurrence of macro-cracks in the examined interlayer bonding and adopted as a criterion for destruction. For that moment of the test, the value of the displacement $u_{m}$ occurring in the bonding and the value of the shear stiffness modulus $\Delta K_{m}$ were determined.

For the model description of the bonding fatigue life, the Wöhler law was used according to the following equation [6]:

$$
\Delta \tau=a \cdot N_{m}^{b}
$$

where:

$\Delta \tau$ - range of the shear stress defined as the ratio of shear force range to the initial shear surface of the sample [MPa], $N_{m}$ - number of load cycles until the occurrence of macro-cracks in the bonding [-], $a, b$ - coefficients calculated by linear regression. 


\section{Preparation of SAMPLeS}

The tests used layered cylindrical samples prepared by the static method. Stone mastic asphalt with a maximum aggregate size equal to $11 \mathrm{~mm}$ (SMA 11) was used for the wearing course and asphalt concrete with a maximum aggregate size equal to $20 \mathrm{~mm}$ (AC 20) was used for the binder course. An example of a sample prepared for the test is shown in Figure 1.

Three variants of performing the bonding and their summaries are given in Table 2.

Table 2. Summary of interlayer bonding variants

\begin{tabular}{|c|c|}
\hline Description of the bonding conditions & Series designation \\
\hline Modified bituminous emulsion tack coat & $\mathrm{F}$ \\
\hline Lack of tack coat & $\mathrm{G}$ \\
\hline Geosynthetic glued by modified bituminous emulsion & $\mathrm{H}$ \\
\hline
\end{tabular}

In the F series, polymer modified bituminous emulsion in an amount of $0.2 \mathrm{~kg} / \mathrm{m}^{2}$ of the remaining asphalt was used as a tack coat. The G Series included the interlayer bonding in which no tack coat was introduced to form a bonding layer. In the $\mathrm{H}$ series, a glass-carbon grid, designed for the reinforcement of asphalt pavement layers and glued through modified bituminous emulsion in the amount of $0.18 \mathrm{~kg} / \mathrm{m}^{2}$, was introduced [18]. The spreading of the emulsion and the geosynthetic was performed manually. Samples with a geosynthetic interlayer were made with a diameter of 150.0 $\mathrm{mm}$ and the others, a diameter of $101.5 \mathrm{~mm}$. The tests were carried out on 90 samples. The detailed sample preparation method was described in [8].

\section{ANALYSIS OF THE CORRELATION BETWEEN SELECTED STATIC AND FATIGUE TEST RESULTS}

By comparing the results of static and fatigue tests, certain trends and relationships occurring between them were sought. The values of the selected parameters determined in laboratory tests were subject to analysis. 


\subsection{Parameters Selected fOr ANALYSIS}

A comparison of the parameters listed in Table 3 was conducted.

Table 3. Summary of compared parameters

\begin{tabular}{|c|c|c|c|}
\hline \multicolumn{2}{|l|}{ STATIC TESTS } & \multicolumn{2}{|l|}{ FATIGUE TESTS } \\
\hline Parameter & Designation & Parameter & Designation \\
\hline Average shear strength & $\tau_{c a}$ & $\begin{array}{c}\text { Directional coefficient of fatigue } \\
\text { curve }\end{array}$ & $\mathrm{a}$ \\
\hline $\begin{array}{l}\text { Average value of adjusted } \\
\text { displacement }\end{array}$ & $p_{k a}$ & $\begin{array}{l}\text { Average displacement at the time of } \\
\text { macro-crack }\end{array}$ & $u_{m a}$ \\
\hline $\begin{array}{l}\text { Average value of interlayer reaction } \\
\text { tangential modulus }\end{array}$ & $K_{a}$ & $\begin{array}{l}\text { Average value of shear stiffness } \\
\text { modulus at the time of macro-crack }\end{array}$ & $\Delta K_{m a}$ \\
\hline
\end{tabular}

\subsection{ANALYSIS OF THE RESULTS OF STATIC STRENGTH AND THE COEFFICIENT OF FATIGUE CURVE}

It was observed that the value of the directional coefficients of the Wöhler fatigue curves obtained for the tested contact conditions corresponds to the average shear strength tested in the static test. Compared values with the basic statistics are summarized in Table 4. The Wöhler fatigue curves were described in detail and illustrated in [9].

Table 4. Values of shear strength and directional coefficient of the fatigue curve for the tested series

\begin{tabular}{|c|c|c|c|c|}
\hline Series & $\begin{array}{c}\text { Average static } \\
\text { strength }\end{array}$ & $\begin{array}{c}\text { Standard deviation } \\
\text { of static strength }\end{array}$ & $\begin{array}{c}\text { Directional } \\
\text { coefficient } \\
\text { of fatigue curve }\end{array}$ & $\begin{array}{c}\text { Coefficient } \\
\text { of determination } \\
\text { of fatigue curve }\end{array}$ \\
\hline F & 2,33 & 0,45 & 2,12 & 0,82 \\
\hline $\mathrm{G}$ & 2,38 & 0,32 & 2,25 & 0,74 \\
\hline
\end{tabular}

Among the values of the compared parameters, there were some differences. Distribution of the results of static strength $\left(\mathrm{F}_{\text {stat }}, \mathrm{G}_{\text {stat }}, \mathrm{H}_{\text {stat }}\right)$ together with a standard deviation and values of the directional coefficient of fatigue curves $\left(F_{\text {fat }}, G_{\text {fat }}, H_{\text {fat }}\right)$ for each series are shown graphically in Figure 5 . 


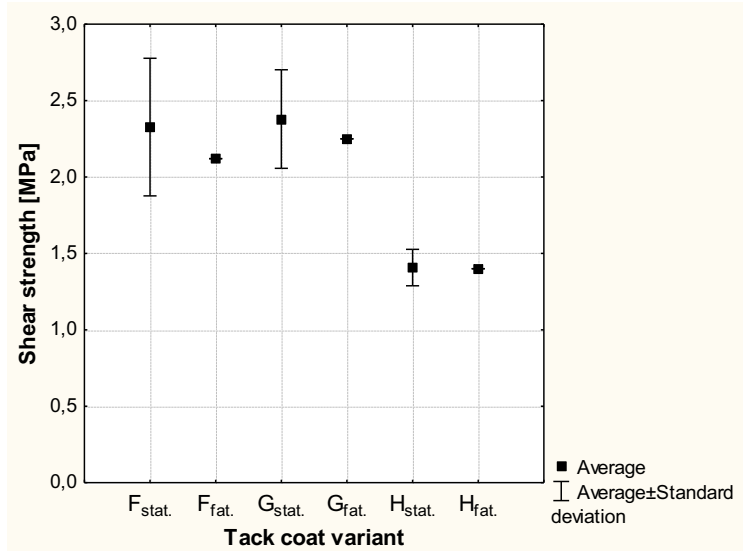

Fig. 5. Distribution of the results of static and fatigue tests for each series

The observed differences were most likely due to the randomness of the fatigue process. Therefore, it was necessary to conduct a statistical analysis to assess the occurrence of significant differences between the parameters. For this purpose, the Student's t-test was used to compare the value of the statistical parameter $t$, determined according to Eq. (4.1), with its critical value [19].

$$
t=\left|\tau_{c a}-a\right| / s \cdot \sqrt{n}
$$

where:

$\tau_{c a}$ - average static shear strength of the bonding [MPa], $a$ - directional coefficient

of fatigue curve, $s$ - standard deviation of the average static strength, $n$ - number of static strength test results.

The analysis was performed at the significance level of 0.05 for the number of degrees of freedom equal to 3 . The results were summarized in Table 5 .

Table 5. Summary of the analysis results of the significance of differences in average shear strength and directional coefficients of fatigue curves

\begin{tabular}{|c|c|c|c|}
\hline Series & F & G & H \\
\hline Average static shear strength & 2,33 & 2,38 & 1,41 \\
\hline Value of the directional coefficient of fatigue curve & 2,12 & 2,25 & 1,40 \\
\hline Statistical parameter $t$ & 0,92 & 0,80 & 0,13 \\
\hline Critical value of the parameter $t$ & 3,18 & 3,18 & 3,18 \\
\hline
\end{tabular}


For all analyzed series, statistical parameter $t$ value was less than the critical value for the accepted level of significance. Therefore, there were no statistically significant differences between the average static strength and the value of the directional coefficient of fatigue curve.

Confirmation of the presence of such a relationship is an important element that can be used in the future for the construction of regression models for interlayer bonding durability for the various contact conditions based on the results of static strength tests.

\subsection{ANALYSIS OF THE DISPLACEMENT RESULTS}

In the next step of the analysis, the average values of adjusted displacement from static tests $p_{k a}$ and the values of displacement at the time of macro-crack $u_{m a}$ were compared. The analysis assumes that the shear strength $\tau_{c a}$ is treated as a range of shear stress $\Delta \tau$. Distribution of results is shown in Figure 6 . The three results on the right side of the graph relate to displacement obtained in static tests $p_{k a}$ and the results on the left side of the graph relate to fatigue tests.

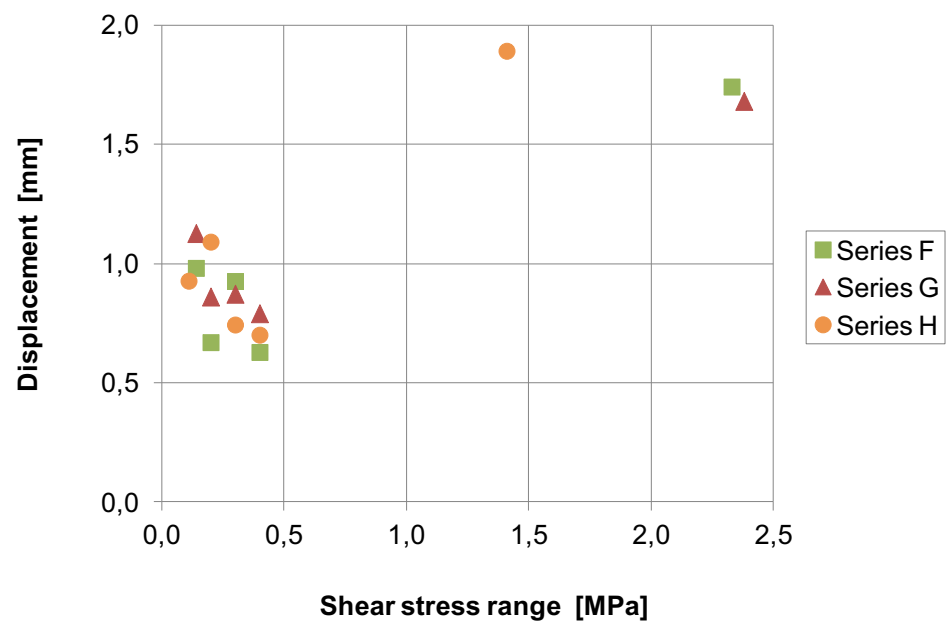

Fig. 6. Distribution of displacement results in static and fatigue tests

The test results indicate that the value of adjusted displacement in static tests is about twice higher than the average displacement at the moment of macro-crack obtained in fatigue tests. It is difficult, however, to clearly indicate the impact of the variant of bonding conditions on the resulting displacement value. 


\subsection{ANAlysis OF MODUli RESUlts}

In a similar way, the average values of shear stiffness modulus $\Delta K_{m a}$ were compared for the applied stress ranges and interlayer reaction tangential moduli $K_{a}$ determined in static tests. The distribution of the results is shown in Figure 7. The three results on the right side of the graphs $7 \mathrm{a}$ and $7 \mathrm{~b}$ concern moduli $K_{a}$ obtained in the static tests.

a)

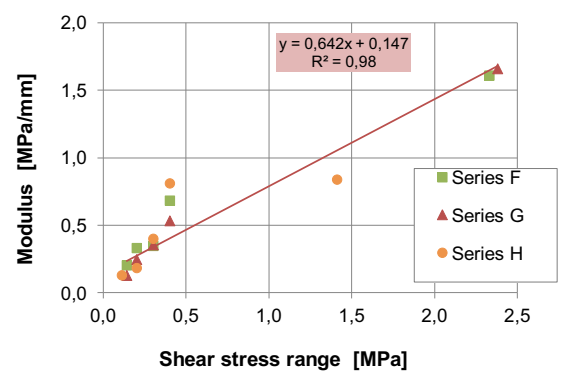

b)

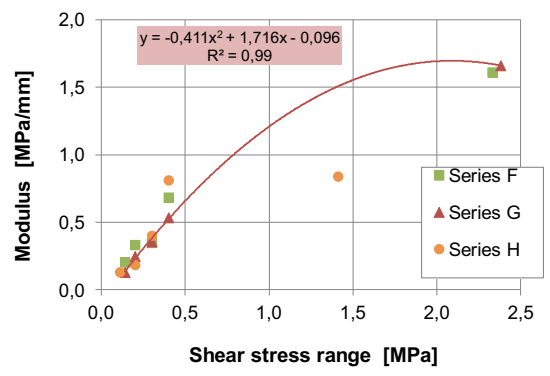

Fig. 7. Distribution of results of shear stiffness modulus and interlayer reaction tangential modulus together with the rectilinear (a) and curved (b) function adjustment for the results of the G series

The distribution of results indicates the existence of a clear trend. Interlayer reaction tangential moduli values are in the area of extrapolation of shear stiffness moduli trend obtained in the fatigue tests. It is possible to determine both straight and curved dependencies between them. For example, for interlayer bondings without a tack coat ( $\mathrm{G}$ series), a very good correlation for both linear (Fig. 7a) and curved function (Fig. 7b) was obtained. In order to determine the final relationships, it is necessary to undertake further static and fatigue tests.

\section{Conclusions}

In this paper, the selected results of static and fatigue tests based on the presented method were compared. The results of the analysis confirmed the presence of significant correlations among the selected test parameters of asphalt mixture interlayer bondings:

- No statistically significant difference between the average values of the shear strength in the static tests and the directional coefficients of fatigue curves was proved.

- Adjusted displacement in static tests takes a value about twice as high than the displacement at the moment of macro-crack in fatigue tests. 
- Interlayer reaction tangential moduli values from the static tests are in an area of extrapolation of shear stiffness moduli trend obtained in fatigue tests.

These results are crucial and, in the future, can be used to build regression models for interlayer bonding durability for various contact conditions based on the results of quick and relatively easy static studies. It is also reasonable to carry out further work on this issue because its results are important from the scientific, technical and economic point of views.

\section{ACKNOWLEDGMENT}

Research co-financed from the funds of the Ministry of Science and Higher Education for its statutory activities under the contract number: L-2/283/2015/DS.

\section{REFERENCES}

1. F. Canestrari, G. Ferrotti, M. N. Partl, E. Santagata, "Advanced testing and characterization of interlayer shear resistance", The 84th TRB Annual Meeting, Washington, USA, 9 - 13 January 2005, CD-ROM

2. J. Judycki, P. Jaskuła, "Modelowanie teoretyczne wpływu sczepności międzywarstwowej na zachowanie się nawierzchni asfaltowych", Report from the third stage, prepared on behalf of GDDKiA, Gdańsk University of Technology, Gdańsk, Poland, 2013

3. J. Górszczyk, "Wpływ zbrojenia geosyntetyczną warstwą pośrednią na trwałość zmęczeniową asfaltowej nawierzchni drogowej" (Influence of the geosynthetic reinforcement on fatigue life of the asphalt pavement), PHD thesis, Cracow University of Technology, Cracow, Poland, 2010

4. J. Górszczyk, S. Gaca, "The influence of the carbo-glass geogrid-reinforcement on the fatigue life of the asphalt pavement structure", Archives of Civil Engineering, 58, 1, 97-113, 2012

5. P. Zieliński, "Investigations of fatigue of asphalt layers with geosynthetics", Archives of Civil Engineering, 59, 2, 247-263, 2013

6. M. Diakhate, Ch. Petit, A. Millien, A. Phelipot-Mardele, B. Pouteau, H. Goacolou, 'Interface fatigue cracking in multilayered pavements: Experimental analysis", Proceedings of the 6th Rilem International Conference on Cracking in Pavements, Chicago, USA, 16 - 18 June 2008, p. 649-659

7. P. Jaskuła, "Badania i analizy sczepności międzywarstwowej w nawierzchniach asfaltowych”, Budownictwo i Architektura, 13, (4), 117-125, 2014

8. K. Malicki, "Analiza połączeń międzywarstwowych mieszanek mineralno-asfaltowych w warunkach obciążeń statycznych i zmęczeniowych" (Analysis of the interlayer bonding in asphalt layers in monotonic and cyclic load conditions), PHD thesis, Cracow University of Technology, Cracow, Poland, 2012

9. J. Górszczyk, K. Malicki, "Influence of the tack coat material on interlayer bonding properties in asphalt layers system", Proceedings of the 4th European Pavement and Asset Management Conference, Malmo 5 - 7 September, Sweden, 2012

10. J. Górszczyk, K. Malicki, "Trwałość zmęczeniowa połączeń warstw asfaltowych w badaniach laboratoryjnych", Zeszyty Naukowe Politechniki Rzeszowskiej, Budownictwo i Inżynieria Środowiska, Zeszyt 59 (3/2012/IV), p. 199 - 206, Rzeszów, Poland, 2012

11. Arbeitsanleitungen zur Prüfung von Asphalt. Teil 4: "Prüfung des Schichtenverbundes nach Leutner", FGSV, Köln, Germany, 1999 
12. P. Jaskuła, ’Instrukcja laboratoryjnego badania sczepności międzywarstwowej warstw asfaltowych wg metody Leutnera i wymagania techniczne sczepności”, GDDKiA, Gdańsk University of Technology, Gdańsk, Poland, 2014

13. W. Van Dijk,'Practical fatigue characterization of bituminous mixes". Annual meeting of the Association of Asphalt Paving Technologists, Vol. 44, p. 38-74, Phoenix, USA, 1975

14. R. Leutner, H. Lorenzl, K. Schmoeckel et al., "Stoffmodelle zur Voraussage des Verformungswiderstandes und Ermüdungsverhaltens von Asphaltbefestigungen". Berichte der Bundesanstalt für Straßenwesen, Heft S 45, Bergisch Gladbach, Germany, 2006

15. G. Rowe, "Performance of Asphalt Mixtures in the trapezoidal Fatigue Test", Proceedings of the Association of Asphalt Paving Technologists, 62, p. 344-384, 1993

16. D. Sybilski, A. Wróbel, W. Bańkowski, ”Opracowanie i weryfikacja badania zmęczenia lepiszczy asfaltowych - Temat WS 07”, Road and Bridge Research Institute, Pavement Technology Division, Warsaw, Poland, 2007

17. W. Bańkowski, "Analiza trwałości zmęczeniowej kompozytów mineralno-asfaltowych metodą konwencjonalną oraz metodą energii rozproszonej", PHD thesis, Faculty of Civil Engineering, Warsaw University of Technology, Poland, 2006

18. "Geosyntetyki S \& P do wzmacniania nawierzchni asfaltowych", Technical approval IBDiM Nr AT/2008-031515, Warsaw, Poland, 2008

19. P. Konieczka, J. Namieśnik et al., group work, "Ocena i kontrola jakości wyników pomiarów analitycznych", WNT, Warsaw, Poland, 2007 


\section{LIST OF FIGURES AND TABLES:}

Fig. 1. The Leutner apparatus for testing asphalt mixture interlayer bondings under shear load together with the sample prepared for testing

Rys. 1. Aparat Leutnera do badań połączeń międzywarstwowych MMA pod obciążeniem ścinającym wraz z próbką przygotowaną do badania

Tab. 1. Parameters of bonding operation description for selected stages

Tab. 1. Parametry opisu pracy połączenia dla wybranych etapów

Fig. 2. Equilibrium path of the interlayer bonding performance for the G1 sample with a diameter of $100 \mathrm{~mm}$ Rys. 2. Ścieżka równowagi pracy połączenia międzywarstwowego dla próbki o średnicy $100 \mathrm{~mm}$

Tab. 2. Summary of interlayer bonding variants

Tab. 2. Zestawienie wariantów połączenia międzywarstwowego

Fig. 3. Stand for fatigue tests using shearing

Rys. 3. Stanowisko do badań zmęczeniowych metodą ścinania

Tab. 3. Summary of compared parameters

Tab. 3. Zestawienie porównywanych parametrów

Fig. 4. Displacement in interlayer bonding of G5 sample during the fatigue test

Rys. 4. Przemieszczenie w połączeniu międzywarstwowym próbki G5 w trakcie badania zmęczeniowego

Tab. 4. Values of shear strength and directional coefficient of the fatigue curve for the tested series

Tab. 4. Zestawienie wartości wytrzymałości na ścinanie i współczynnika kierunkowego równania zmęczeniowego dla badanych serii

Fig. 5. Distribution of the results of static and fatigue tests for each series

Rys. 5. Rozkład wyników badań statycznych i zmęczeniowych dla poszczególnych serii

Tab. 5. Summary of the analysis results of the significance of differences in average shear strength and directional coefficients of fatigue curves

Tab. 5. Zestawienie wyników analizy istotności różnic średnich wytrzymałości na ścinanie i współczynników kierunkowych krzywych zmęczeniowych

Fig. 6. Distribution of displacement results in static and fatigue tests

Rys. 6. Rozkład wyników przemieszczenia w badaniach statycznych i zmęczeniowych

Fig. 7. Distribution of results of shear stiffness modulus and interlayer reaction tangential modulus together with the rectilinear (a) and curved (b) function adjustment for the results of the G series Rys. 7. Rozkład wyników modułów sztywności ścinania i modułów stycznych wraz z dopasowaniem regresyjnym funkcji prostoliniowej (a) oraz krzywoliniowej (b) dla wyników serii G 


\section{ANALIZA ZALEŻNOŚCI POMIĘDZY WYNIKAMI STATYCZNYCH I ZMĘCZENIOWYCH BADAŃ POLĄCZEŃ MIĘDZYWARSTWOWYCH WARSTW MINERALNO-ASFALTOWYCH}

Slowa kluczowe: połączenie międzywarstwowe mieszanek mineralno-asfaltowych, trwałość zmęczeniowa

\section{STRESZCZENIE:}

Konstrukcja podatnej nawierzchni drogowej składa się w górnej części z połączonych ze sobą warstw mieszanek mineralno-asfaltowych (MMA). Stan tego połączenia odgrywa istotną rolę w trwałości całej konstrukcji. W przypadku braku właściwego związania następuje osłabienie połączenia międzywarstwowego i przyspieszenie degradacji nawierzchni. Zazwyczaj do laboratoryjnej oceny stanu połączeń międzywarstwowych wykorzystywane są stosunkowo łatwe i szybkie metody statyczne. Jednak połączenia międzywarstwowe pracują pod obciążeniem dynamicznym od kół pojazdów samochodowych. Zatem ich degradację w czasie należy rozpatrywać raczej jako proces zmęczeniowy.

W niniejszej pracy podjęto próbę analizy zależności pomiędzy wynikami badań statycznych a wynikami badań zmęczeniowych połączeń międzywarstwowych realizowanych w warunkach ścinania. Porównując wyniki poszukiwano występowania pomiędzy nimi istotnych zależności i tendencji. Analizy zmęczeniowe oparto na wynikach uzyskanych wg własnej laboratoryjnej metody badawczej.

Badania połączeń międzywarstwowych przeprowadzono w trybie ścinania $\mathrm{w}$ aparacie Leutnera $\mathrm{z}$ zastosowaniem obciążenia statycznego oraz cyklicznego powodującego proces zmęczeniowy. Badania przeprowadzono w temperaturze $+20^{\circ} \mathrm{C}$. W niniejszej pracy przedstawiono jedynie wybrane parametry oraz najważniejsze elementy zastosowanych metod badań a ich szerszy opis znajduje się w literaturze.

Analiza otrzymanej ścieżki równowagi w badaniach statycznych umożliwia wyróżnienie czterech charakterystycznych etapów pracy połączenia, które mogą zostać opisane za pomocą wybranych parametrów. Zerowy etap o zmiennej długości występuje na początku badania i związany jest z dopasowaniem próbki do aparatury badawczej. Nie jest on uwzględniany w zasadniczym opisie pracy materiału. W kolejnym, pierwszym etapie pracy widoczny jest okres stabilnej odpowiedzi badanego połączenia. Metodą regresji wyznaczana jest prosta styczna do wykresu naprężenie przemieszczenie. Przedłużenie linii regresji do osi odciętych umożliwia wprowadzenie parametru przemieszczenia skorygowanego pozwalającego na eliminację wpływu zerowego etapu na dalszy opis pracy połączenia. Parametr ten został zdefiniowany jako przemieszczenie pomiędzy punktem przecięcia linii stycznej do wykresu z osią odciętych a przemieszczeniem odpowiadającym maksymalnemu naprężeniu stycznemu. Uzyskana zależność liniowa opisuje stałą sztywność połączenia na tym etapie jego pracy. Sztywność ta może zostać wyrażona przy użyciu modelu Goodmana. Drugi, chwilowy etap dotyczy momentu wystąpienia maksymalnego naprężenia stycznego. Parametrem oceny tego etapu jest wytrzymałości połączenia na ścinanie, zdefiniowana jako stosunek maksymalnej zadanej siły ścinającej do pola powierzchni próbki poddanego ścinaniu. Po uzyskaniu maksymalnej wartości naprężenia stycznego następuje trzeci umowny etap pracy w którym zakłada się, iż połączenie ulega zniszczeniu i przestaje przenosić obciążenie. Wyróżniono zatem cztery etapy pracy połączenia (łącznie z zerowym), natomiast do dalszych analiz wybrano etapy pierwszy i drugi.

W rozwoju metod badań wytrzymałości połączeń międzywarstwowych opracowano metodę bezpośredniego ścinania pod obciążeniem cyklicznym. Badania zrealizowano w trybie kontrolowanego naprężenia o współczynniku asymetrii cyklu $\mathrm{R}=0$. Zastosowano obciążenie o częstotliwości $0,833 \mathrm{~Hz}$, z czasem trwania wynoszącym $240 \mathrm{~ms}$. 
Opracowana metoda badań zmęczeniowych została oparta na koncepcji energii rozproszonej Van Dijk’a, która znalazła szerokie wykorzystanie w badaniach procesu zmęczenia MMA. W metodzie zakłada się występowanie trzech faz degradacji materiału: początkowej fazy stabilizacji, fazy inicjacji i propagacji mikropęknięć oraz fazy powstania i propagacji makropęknięcia aż do zniszczenia materiału.

Wykorzystując parametr energii rozproszonej na początku badania oraz energii rozproszonej w danym cyklu obciążenia wyznaczany jest ich stosunek, który zapisywany jest symbolem ER (Energy Ratio). Może on być reprezentowany poprzez iloczyn modułu sztywności MMA w danym cyklu obciążenia oraz liczby cykli obciążenia N.

W badaniach wykorzystano warstwowe próbki cylindryczne przygotowane metodą statyczną. Na warstwę ścieralną użyto mieszankę grysowo-mastyksową (SMA 11), a na warstwę wiążącą beton asfaltowy (AC 20). Rozważno trzy warianty wykonania połączenia.

Zaobserwowano, iż wartość współczynników kierunkowych krzywych zmęczeniowych Wöhlera uzyskanych dla badanych warunków kontaktu koresponduje z średnią wytrzymałością na ścinanie badaną w próbie statycznej.

Potwierdzenie występowania takiej zależności stanowi istotny element, który może zostać w przyszłości wykorzystany przy budowie modeli regresyjnych trwałości połączeń międzywarstwowych dla różnych warunków kontaktu w oparciu o wyniki badań wytrzymałości statycznej.

Wyniki badań wskazują, iż przemieszczenie skorygowane w badaniach statycznych przyjmuje około dwukrotnie wyższą wartość niż średnie przemieszczenie w momencie makropęknięcia uzyskane w badaniach zmęczeniowych. Trudne jest natomiast wskazanie wyraźnego wpływu wariantu wykonania połączenia na uzyskaną wartość przemieszczenia.

Uzyskany rozkład wyników wskazał na występowanie wyraźnej tendencji. Wartości modułów stycznych znajdują się w obszarze ekstrapolacji trendu modułów sztywności ścinania uzyskanych w badaniach zmęczeniowych. Możliwe jest wyznaczenie między nimi zarówno zależności prosto jak i krzywoliniowych. Dla połączeń międzywarstwowych bez warstwy sczepnej uzyskano bardzo dobrą korelację zarówno dla funkcji prostoliniowej jak i dla funkcji krzywoliniowej. W celu wyznaczenia ostatecznych zależności konieczne jest podjęcie dalszych badań statycznych i zmęczeniowych.

Rezultaty przeprowadzonych analiz potwierdziły występowanie istotnych zależności pomiędzy wybranymi parametrami badań połączeń międzywarstwowych MMA. Uzyskane rezultaty stanowią ważny krok i mogą zostać w przyszłości wykorzystane przy budowie modeli regresyjnych trwałości połączeń międzywarstwowych dla różnych warunków kontaktu w oparciu o wyniki szybkich i stosunkowo łatwych badań statycznych. Zasadne jest również prowadzenie dalszych prac dotyczących tego zagadnienia, gdyż ich wyniki są istotne zarówno z punktu widzenia naukowo-technicznego jak i ekonomicznego. 